\title{
Working Capital Management and the Profitability of the Manufacturing Sector: A Case Study of Pakistan's Textile Industry
}

\section{Shahid Ali*}

\begin{abstract}
This study explores the association between working capital management and the profitability of textile firms in Pakistan. The efficiency of working capital management is reflected by three variables: cash conversion efficiency, days operating cycle, and days of working capital. We use return on assets, economic value added, return on equity, and profit margin on sales as proxies for profitability. A balanced panel dataset covering 160 textile firms for the period 2000-05 is analyzed and we estimate an ordinary least squares model and a fixed effect model. Return on assets is found to be significantly and negatively related to average days receivable, positively related to average days in inventory, and significantly and negatively related to average days payable. Also, return on assets has a significant positive correlation with the cash conversion cycle, which would suggest that a longer cash conversion cycle is more profitable in the textiles business. The findings of the regression analysis show that average days in inventory, average days receivable, and average days payable have a significant economic impact on return on assets. The findings of the fixed effect model reveal that average days in inventory and average days receivable both have a significant impact on return on assets.
\end{abstract}

Keywords: Working Capital, profitability, textile sector, Pakistan.

\section{JEL Classification: G32, C33.}

\section{Introduction}

Corporate finance is an area of immense importance for business organizations. The decisions made by financial managers significantly affect the overall profitability of a business organization as well as the interests of a wide variety of stakeholders. Managers adopt risk minimization strategies and, accordingly, take a series of well-organized measures to ensure day-today operational smoothness, which not only helps to avoid insolvency but also enhances the prospects of profitability for the organization.

\footnotetext{
* Assistant Professor, Institute of Management Sciences, Peshawar, Pakistan,.
} 
The management of working capital is a major part of managing financial operations as it is thought to be linked to profitability. Working capital efficiency appears to be a function of credit policy and the costefficient supply of raw material and inputs. Frequently, managers encounter trade-off situations in their endeavors. For instance, improving the efficiency of accounts receivable can generate bad debts; allowing for discounts can improve the collection of receivables but the fast collection of receivables can also lead to lost sales due to a strict credit policy. A sound working capital management (WCM) policy is usually structured around the consideration of these realities.

In this context, it makes sense to look at how profitability behaves in relation to working capital practices. This study examines the same for the textiles sector, in the hope to reveal certain extra caveats. In particular, one could ask a number of interesting questions in this context. Is there a blend of current assets that is more beneficial? Can a particular working capital strategy be more rewarding for indigenous business firms? How many days of working capital (DWC) should textile firms hold? Does this vary over a period of time or does it vary from company to company? Can a relationship be established between the efficiency of working capital and higher profitability? These questions could generate important guidelines for the implementation of policy planning in Pakistan.

The results of the study will most likely be useful in understanding the dynamics of and, thus, in improving WCM practices toward maximizing profitability. It could help guide financial managers toward more specialized handling of day-to-day operations and achieving optimal levels for increased efficiency. The results drawn from the experience of the textiles sector could lead to valuable conclusions for other sectors of Pakistan's economy. Here, we analyze the experience of 160 textile firms for the period 2000-05 on the basis of secondary data. The sample includes three main types of firms: spinning, weaving, and composite, and our main data sources include the State Bank of Pakistan and Business Recorder.

Section 2 discusses the relevant literature, while Section 3 describes the sources of data and methodology used. Section 4 analyzes the data, and Section 5 presents our statistical findings. Finally, Section 6 provides a summary and conclusions. 


\section{A Review of the Literature}

The literature on this topic has grown significantly in recent years. Surprisingly, there is, largely, consensus among different authors, who identify almost similar determinants of WCM. A number of studies find that there is a positive association between WCM and profitability. Shin and Soenen (1998) investigate 58,985 firm-year data for the period 197594, to identify the relationship between a firm's profitability and net trade cycle. The evidence they derive from their analysis implies a strong negative relationship between the two variables.

There has also been some work on Pakistan's anti-dumping laws in relation to textile business practies. Since prices in local and international markets are a major concern, the investigation of these laws has implications for working capital policies that affect the cost of production in local markets. Yazdani (1999) makes an interesting contribution to the research in this area: he emphasizes the role of government intervention in minimizing the effects of dumping on the profits of textile firms, who require huge resources to monitor and reduce the impact of dumping. In addition to these effects, overall production costs can have grave consequences for firms.

Lyroudi and Lazaridis (2000) have conducted a study on similar grounds of the Greek food and beverage industry. They find that a positive relationship exists between the cash conversion cycle (CCC) and current and quick ratios, and between the CCC and return on assets (ROA). The profit margin is observed to move positively with CCC, and the latter is found to have no association with leverage ratios.

Anand and Gupta's (2001) empirical survey of working capital performance in corporate India helps identify the core determinants of WCM. Their study investigates the working capital performance of 427 of the S\&P-500 companies over the period 1998/99 to 2000/01. They argue that cash conversion efficiency (CCE), DWC, and days operating cycle (DOC) are the key variables that chief financial officers need to keep in mind when making decisions regarding higher profitability.

The above-mentioned studies seem to derive their conclusions by assuming a number of circumstantial factors to be constant. Linking profitability to improved WCM practices alone is far from reality where there may be a dozen overriding factors that affect a firm's profitability. With working capital, there is the possibility of seasonal factors being associated with profitability; credit requirements, business expansion, 
and firms' credit policy are other important considerations. These, however, have been largely neglected by the aforementioned studies.

Deloof (2003) suggests, on the basis of a study of 1,009 nonfinancial firms in Belgium over the period 1992-96, that managers may find it possible to maximize shareholders' wealth by improving WCM efficiency. The author argues that doing so is made possible by the fast collection of receivables and by keeping an optimal level of inventory. The study finds that gross operating income moves in an opposite direction to average days receivable (DR), average days in inventory (DI), average days payable (DP), and CCC. The analysis also reveals a negative relationship between accounts payable and profitability, which is consistent with the view that less-profitable firms wait longer to pay their bills. The study also finds that bills receivable have a highly significant negative relationship with profitability.

The Deloof (2003) study raises a number of critical arguments, such as that firms in such a large sample must vary in terms of size, age, technology, and asset size, etc. Liquidity issues will vary greatly depending on the risk settings of businesses in the sample; and firms will have different credit ratings shaping the dynamic buying patterns of purchase. Kemal (2005) discusses industrial problems in Pakistan and argues that, despite the growth in industrial production, investment levels have fallen. He identifies multiple factors in this respect, including high production and transaction costs, and allocative, technical, and X-inefficiencies.

Khan, Shah, and Hijazi (2006) have conducted a study of 30 listed nonfinancial firms in Pakistan to analyze the impact of WCM on profitability. Their results show a significant negative relationship between firms' gross profit and the average number of DI and DP, and CCC. But with such narrow datasets, the results can hardly be generalized across different sectors. Lazaridis and Tryfonidis (2006) take the case of 131 firms listed on the Athens stock exchange with the same objective as Khan et al. Their study relies on a five-year panel dataset, and shows that the CCC significantly affects the profitability of firms. This argument reflects the relationship between managing working capital and increasing firm value.

Shah and Sana (2006) also investigate this relationship, using financial data on oil and gas companies in Pakistan for the period 2001 to 2005. Their findings suggest that it is possible for financial managers to maximize shareholders' wealth by efficiently managing working capital. They report that profit margins move in a significantly opposite direction to 
receivables, cash cycles, sales growth, and inventory conversion periods. Further, they examine the causal relationship that confirms that the efficient management of working capital moves positively with profitability.

Padachi (2006) uses a set of 58 small manufacturing firms in Mauritius with 340 firm-year observations from 1998 to 2003. The study confirms that firms with more receivables and higher levels of inventory are less profitable. The author conducts a comparative analysis of five major industry groups, and asserts that working capital has a negative correlation with ROA. The study concludes that the efficient management of working capital increases profitability.

WCM is thus deemed an essential tool that helps measure both the operational and financial efficiency of a business firm. Raheman and Nasr (2007), who analyze financial data on 94 Pakistani firms listed on the Karachi Stock Exchange for the period 1999 to 2004, reiterate this message. Their main finding is that liquidity and profitability are negatively related and that the association is significant as well. The study supports some earlier studies in that it establishes the negative association between firms' profitability and the different components of working capital.

Garcia-Teruel and Martinez-Solano (2007) use financial data on 8,872 Spanish firms for the period 1996 to 2002 to investigate the effects of WCM on profitability. Their investigation reveals the obvious: that profitability increases if the contributing factors of working capital are efficiently managed. They summarize that profitable firms collect their receivables early, take less time to convert their inventories into finished goods, pay their dues early, and have a short CCC. Previous similar studies have focused more on large firms and attempted to explore the relationship between the micromanagement of working capital and its effects on profitability (see, for example, Shin \& Soenen, 1998).

Authors like Anand and Malhotra (2007) have attempted to develop objective metrics to measure efficiency at the industry and firm level. Using data on 339 Indian companies for the period 2001/02 to 2003/04, the authors report that the firms' operating cycles and CCCs are both reduced, but they cannot establish a positive relationship between profitability and the efficient management of working capital.

Burki (2008) looks at the industrial performance of Pakistani firms by investigating the efficiency standards adopted by local business firms. The aim of this particular study is to monitor the effects of efficiency on the public policy in place. The research focuses on the government's need 
to adjust to a macroeconomic balance; it measures the impact of global industrial practices on indigenous practices, and emphasizes a decentralized industrial policy. The author sets a picture in which efficiency can be achieved on the broader economic horizon, and makes a number of policy suggestions that could help local firms attain higher business efficiency.

Summing up, the issue has been well researched around the world. Some authors argue that there is a significant positive relationship between WCM and profitability, while others disagree. Most studies on Europe indicate that a firm can be more profitable if working capital is managed efficiently. Studies on India report mixed findings, while those on Pakistan confirm the positive association. However, the issue remains open to further research.

\section{Methodology and Data}

Our study is designed to initially rank textile firms in Pakistan on the basis of objective metrics of WCM and profitability, and then find any rank correlation between them. The following hypotheses will be tested, using the data.

$\mathrm{H}_{01}$ : There is positive rank correlation between WCM and the profitability of textile firms.

$\mathrm{H}_{02}$ : The cash cycle affects the profitability of these firms.

$\mathrm{H}_{03}$ : A shorter inventory conversion period has an economic impact on the ROA employed by each firm.

$\mathrm{H}_{04}$ : A shorter average collection period for receivables has a positive impact on ROA.

$\mathrm{H}_{05}$ : Textile firms with longer average DP are less profitable.

We adopt an extended form of the well-known methodology given by Anand and Gupta (2001) — used to determine the working capital performance of nonfinancial firms in India-and devise a similar model for profitability. Textile firms are ranked both on the basis of a working capital performance ranking (WCPR) model and a profitability performance ranking (PPR) model. We compute Spearman's rho and Kendall tau_b and test their significance to find support for the stated hypotheses. 
A regression analysis follows to test the significance of the theory that the higher profitability of textile firms is dependent on the explanatory variables of WCM. The regression is performed using both an ordinary least squares (OLS) model and a fixed effects model (FEM). The balanced panel regression analysis using the FEM considers the firm effect, for which dummy variables are created. Since we are using data for only a sixyear period, dummies for time are not created. ROA is taken as an explained variable, while CCE, DI, DP, and DR are explanatory variables.

Numerous factors affect the profitability of textile firms, including pricing policy, sales growth, and total assets, etc. Our regression analysis therefore incorporates the following control variables: the size of the firm (proxied by the natural log of sales), gearing ratio (GR), ratio of current assets to total assets, and gross working capital turnover ratio (GWCTR). The results are given in tabular form and the findings discussed below.

\subsection{Working Capital Management Model (WCM)}

Anand and Gupta's (2001) methodology computes WCPR, using the variables CCE, DOC, and DWC. The definition and computation of these variables is explained below.

\subsubsection{Cash Conversion Efficiency (CCE)}

A textile firm with a higher CCE is deemed more efficient, i.e., in terms of the cash it generates through the effective management of its business, for instance, the sale of goods of a business per unit of sale revenue. First, the net cash flow from operating activities is derived as follows (the Appendix explains the abbreviations used).

$$
\mathrm{NCFFOA}=\mathrm{EBIT}+\mathrm{D}-\mathrm{T}
$$

CCE can be worked out in the second step:

$$
\mathrm{CCE}=\mathrm{NCFFOA} / \mathrm{SR}
$$

A higher CCE indicates greater efficiency in WCM and vice versa. CCE is then converted into a meaningful normalized form so that these values can be measured on a comparable standardized scale:

$$
\mathrm{N}_{\mathrm{cce}}=\left[\left(\mathrm{h}_{\mathrm{comr}}-\mathrm{c}_{\mathrm{comr}}\right) /\left(\mathrm{h}_{\mathrm{comr}}-\mathrm{l}_{\mathrm{comr}}\right)\right]
$$


A firm whose $\mathrm{N}_{\text {cce }}$ equals 0 is considered the best-performing firm in terms of CCE.

\subsubsection{Days Operating Cycle (DOC)}

DOC is a financial metric that shows how fast a firm is able to convert its resources, i.e., the total time (in number of days) that a firm takes to acquire and convert inventories into sellable products, and then recovers in the form of hard cash inflows through cash collection. Theoretically speaking, it uses the following indices:

Days consumption and days cost of sales = inventory average daily cost of sales

Days sales $=$ (account receivable/average daily credit sales $)$

The lower the DOC, the more efficient the firm. DOC is also converted into meaningful normalized form to allow standardized comparison:

$$
\mathrm{N}_{\mathrm{doc}}=\left[\left(\mathrm{l}_{\mathrm{doc}}-\mathrm{c}_{\mathrm{doc}}\right) /\left(\mathrm{l}_{\mathrm{doc}}-\mathrm{h}_{\mathrm{doc}}\right)\right]
$$

A smaller $\mathrm{N}_{\mathrm{doc}}$ indicates a better performer for this parameter.

\subsubsection{Days of Working Capital (DWC)}

DWC is another formula used in short-term decisions by finance managers to actually see the gap or time available between the conversion of less-liquid assets to a more liquid form, and payment of due bills for purchases. The liquidity risk is measured by DWC and is used to decide whether suppliers' credit should be used to finance inventory and receivables or if other sources should be used. Symbolically,

$$
\text { DWC }=\text { DOC }- \text { creditors (days purchases) }
$$

"Days purchases" equals accounts payable divided by average daily purchases. A benchmark efficiency measure for DWC is supposed to be that which is neither higher on positive nor negative scales, and is concentrated where the number of DWC is 0 . DWC is converted into meaningful normalized form as follows:

$$
\mathrm{N}_{\mathrm{dwc}}=\left[\left(1_{\mathrm{dwc}}-\mathrm{c}_{\mathrm{dwc}}\right) /\left(\mathrm{l}_{\mathrm{dwc}}-\mathrm{h}_{\mathrm{dwc}}\right)\right]
$$


A smaller $\mathrm{N}_{\mathrm{dwc}}$ indicates a better performer in managing liquidity risk.

\subsubsection{Working Capital Performance Ranking Model (WCPR)}

Anand and Gupta (2001) suggest the following model and reserve subjective consideration for the assignment of weights to factors. The expression assigns a 50-percent weight to CCE and a 25-percent weight each to DOC and DWC. A manufacturing firm in Pakistan with the lowest overall score based on the above rule would be ranked 1, signifying that it was the best performer in terms of WCM.

$$
\mathrm{WCPR}=\mathrm{N}_{\text {cce }} * 0.50+\mathrm{N}_{\text {doc }} * 0.25+\mathrm{N}_{\text {dwc }} * 0.25
$$

A firm with the lowest overall WCPR score would be ranked 1 and assumed to be the best performer in practicing WCM, and so on. However, the model suffers from the limitation of subjective assignment of weights. A different weight assignment criterion would change the ranking of firms.

\subsection{Profitability Model}

Firms remain under moral and legal obligation to give business returns to their shareholders and to be profitable. Profit is a derivation that has accounting limitations, such as choosing between LIFO, FIFO, or other methods of costing inventories, and the treatment of capital and revenue expenditures. However, in the light of international accounting standards and company byelaws, accounting profit is seldom used in financial analysis. We put forward a model for ranking firms, in which an index is developed by taking the weighted averages of ROA, return on equity (ROE), profit margin on sales (PMS), and economic value added (EVA). They are described and normalized as follows.

\subsubsection{Return on Assets (ROA)}

ROA is a widely used financial tool to determine the level and intensity of returns that a firm has generated by employing its total assets. Firms are usually considered well off when they generate returns that can attract further investors and lenders, and in trouble if they need to raise the finance required for growth or capital needs, or if their ROA does not convince financiers. ROA reflects the earnings generated by the capital invested, and is calculated as follows:

$$
\mathrm{ROA}=\text { net income } / \text { total assets }
$$


ROA is converted into a meaningful normalized form to allow the comparison of textile firms on a standardized scale:

$$
\mathrm{N}_{\text {roa }}=\left[\left(\mathrm{h}_{\text {roa }}-\mathrm{c}_{\text {roa }}\right) /\left(\mathrm{h}_{\text {roa }}-\mathrm{l}_{\text {roa }}\right)\right]
$$

A smaller ROA obtained using this rule indicates a better-performing firm.

\subsubsection{Return on Equity (ROE)}

$\mathrm{ROE}$ is a routine analysis tool that shows the returns a firm has generated using the equity of its owners. It is expressed as:

$$
\text { ROE }=\text { net income/shareholders' common equity }
$$

ROE is converted into meaningful normalized form as follows:

$$
\mathrm{N}_{\text {roe }}=\left[\left(\mathrm{h}_{\text {roe }}-\mathrm{c}_{\text {roe }}\right) /\left(\mathrm{h}_{\text {roe }}-\mathrm{l}_{\text {roe }}\right)\right]
$$

A smaller ROE obtained using this rule indicates a better-performing firm.

\subsubsection{Profit Margin on Sales (PMS)}

PMS is a financial yardstick that shows how much a firm is making (before interest and taxes) for each sale of a dollar amount. Simply understood, a higher PMS means the more economical use of invested money. It is computed as follows:

$$
\text { PMS = operating income } / \text { gross sales }
$$

PMS is converted into meaningful normalized form as follows:

$$
\mathrm{N}_{\mathrm{pms}}=\left[\left(\mathrm{h}_{\mathrm{pms}}-\mathrm{c}_{\mathrm{pms}}\right) /\left(\mathrm{h}_{\mathrm{pms}}-\mathrm{l}_{\mathrm{pms}}\right)\right]
$$

A smaller PMS obtained using this rule indicates a better performing firm.

\subsubsection{Economic Value Added (EVA)}

EVA, a registered trademark of Stern, Stewart \& Co. (Stewart, 1991), is an index that calculates returns after excluding the opportunity cost of the invested capital in the firm. It is calculated as follows:

$$
\text { EVA }=\text { NOPAT }-\left(\text { capital }{ }^{*} \text { cost of invested capital }\right)
$$


The cost of invested capital is calculated using the standard weighted average cost of capital method, in which the cost of equity is assumed to be 100/PE ratio and the cost of debt is taken as the ratio of financial expenses to total fixed liabilities as follows:

$\mathrm{P} / \mathrm{E}$ ratio $=$ current market value per share/earnings per share

Cost of debt $=$ financial expenses $/$ total fixed liabilities

Given the limited availability of data on the entire sample of textile firms included in this study, we use an industry average cost of capital, which is computed to be 11.072 percent on the basis of 414 firmyear observations. A corporate tax rate of 35 percent is used for the said period. This figure is used to compute a firm's EVA. Next, EVA is converted into a meaningful normalized form for standardization purposes as follows:

$$
\mathrm{N}_{\mathrm{eva}}=\left[\left(\mathrm{h}_{\mathrm{eva}}-\mathrm{c}_{\mathrm{eva}}\right) /\left(\mathrm{h}_{\mathrm{eva}}-\mathrm{l}_{\mathrm{eva}}\right)\right]
$$

A smaller EVA obtained using this rule indicates a better-performing firm.

\subsubsection{Profitability Performance Ranking Model (PPR)}

We calculate profitability performance by assigning a 25 percent weight to the four core parameters discussed above, and obtaining a weighted average score for each firm. An equal weight is assigned to each parameter on the premise that any firm with an edge in only one of these parameters cannot outperform another firm; rather, it will need the support of all four equally important parameters to perform better. Equal weights are assigned to all profitability parameters so that firms can be evaluated and ranked on the basis of good economic performance, and such that a firm can be ranked highest when it leads among all other firms in the industry in terms of these parameters. Although assigning weights is a subjective practice and changing them may change firms' ranking, assigning equal weights becomes a uniform importance criterion. The model can be written as follows:

$$
\mathrm{PPR}=\mathrm{N}_{\text {roa }} * 0.25+\mathrm{N}_{\text {roe }} * 0.25+\mathrm{N}_{\text {pms }} * 0.25+\mathrm{N}_{\text {eva }} * 0.25
$$

A firm with a score of 0 is ranked highest on the basis of this benchmark, while a score farther away from 0 indicates lower profitability performance. 
We use the formal Spearman's rho or Kendall tau_b to compute rank correlation in terms of both WCM and profitability for each individual firm for the study period. The t-test is used to determine correlation significance.

\subsection{Theoretical Model and Variables}

The following theoretical model is used to measure the economic impact of working capital variables along with a set of control variables:

$$
\mathrm{ROA}=\mathrm{f}\left(\operatorname{lnS}, \mathrm{GR}, \mathrm{GWCTR}, \mathrm{C}_{\mathrm{t} 1}, \text { ExWC }\right)
$$

This can be rewritten for each component of working capital as follows:

$$
\begin{aligned}
& \text { ROA }=\mathrm{f}\left(\operatorname{lnS}, \text { GR, GWCTR, } \mathrm{C}_{\mathrm{t} 1}, \mathrm{DI}\right) \\
& \text { ROA }=\mathrm{f}\left(\operatorname{lnS}, \mathrm{GR}, \mathrm{GWCTR}, \mathrm{C}_{\mathrm{t} 1}, \mathrm{DR}\right) \\
& \mathrm{ROA}=\mathrm{f}\left(\operatorname{lnS}, \mathrm{GR}, \mathrm{GWCTR}, \mathrm{C}_{\mathrm{t} 1}, \mathrm{DP}\right) \\
& \text { ROA }=\mathrm{f}\left(\ln S, \mathrm{GR}, \mathrm{GWCTR}, \mathrm{C}_{\mathrm{t} 1}, \mathrm{C}_{\mathrm{t} 2}, \mathrm{CCC}\right)
\end{aligned}
$$

LnS is the natural log of sales, $\mathrm{C}_{\mathrm{t} 1}$ denotes current assets divided by total assets, $C_{\mathrm{t} 2}$ denotes current liabilities divided by total assets, and ExWC denotes the explanatory variables DI, DP, DR, and CCC.

A regression analysis is used to identify which explanatory variables affect profitability. Accordingly, ROA is taken as the dependent variable, and DI, DR, DP, and CCC as explanatory variables. Since a number of factors can affect profitability (pricing policy, sales growth, etc.), we use the following control variables: sales as a proxy for firm size (natural $\log$ of sales) along with GR (debt/total assets), GWCTR (sales/current assets), current assets/total assets, and current liabilities/total assets.

\subsection{Estimation of Regression Models}

A balanced panel model (Gujrati, 2003) can be written as:

$$
\mathrm{Y}_{\mathrm{it}}=\beta_{1+} \beta_{2} \mathrm{X}_{2 \mathrm{it}}+\beta_{3} \mathrm{X}_{3 \mathrm{it}}+\ldots .+\mathrm{u}_{\mathrm{it}}
$$

$i=1,2,3, \ldots 160$ (160 textile firms) and $t=1,2,3,4,5,6$ (six years), while $\mathrm{u}_{\mathrm{it}}$ is an error term 
Using OLS, as described by equation (i), we measure the statistical significance of explanatory variables $(X)$ for dependent variable $(Y)$, i.e., the statistical relationship between ROA $(Y)$ and its determinants, $X_{2}$ (natural $\log$ of sales), $X_{3}$ (GR), $X_{4}$ (GWCTR), $X_{5}$ (current assets/total assets), and $\mathrm{X}_{6}$ (working capital variables average DI, average DP, average $\mathrm{DR}$, and $\mathrm{CCC}$ ).

The assumption that $\beta=0$ (taken as the coefficients in the proposed models) in the case of restricted regression is tested. One coefficient relates to any of the variables DI, DR, DP, and cash cycle, while four coefficients are derived using the control variables (firm size, GR, current asset turnover, and ratio of current assets to total assets). The expected sign of $\beta=0$ negates any economic impact of these variables on ROA, if proven insignificant. Next, we assume an unrestricted regression model in which the y-intercept is allowed to vary for each firm from a balanced panel, and dummies are inserted to capture the firm effect.

Using pooled OLS can be subject to the problems of heteroscedasticity, multicollinearity, and autocorrelation. In addition, pooled OLS does not take into account the fixed effects of different economic sectors. This necessitates the use of a panel regression technique, in which a case an FEM or random effects model (REM) is used. In the case of an FEM, a robust (HAC) standard errors model can be used to control for heteroscedasticity and autocorrelation.

If we assume the time invariance of the intercepts of each sampled firm from a respective sector in the pooled regression model (i), the following FEM is used:

$$
Y_{i t}=\beta_{1 i}+\beta_{2} X_{2 i t}+\beta_{3} X_{3 i t}+\ldots .+u_{i t}
$$

The conventional modeling of an FEM is termed a least squares dummy variable model, since a number of dummy variables are incorporated into (i) to capture values of the cross-sectional unit $i$ in the panel set of time series $t$. Modern computer software for econometric modeling has made this very easy. In the FEM described in equation (ii), we assume that $\beta_{1 \mathrm{i}}$ is fixed. If this intercept is assumed to be a random variable where $\beta_{1 \mathrm{i}}=\beta_{1}+\epsilon_{\mathrm{i}}$, then equation (iii) is presented as follows:

$$
Y_{i t}=\beta_{1+} \beta_{2} X_{2 i t}+\beta_{3} X_{3 i t}+\ldots .+w_{i t}
$$

Equation (vii) is described as an REM or error components model, in which $\mathrm{w}_{\mathrm{it}}=\epsilon_{\mathrm{i}}+\mathrm{u}_{\mathrm{it}}$. In this composite error term $\epsilon_{i}$ is the individual- 
specific error component and $\mathrm{u}_{\mathrm{it}}$ is the combined time series and crosssection error component.

Researchers often face the problem of choosing between an FEM and REM, as there are a number of assumptions surrounding the error components mentioned above. Hausman (1978) developed a specification test to help choose an appropriate model, which works on the simple idea that estimators from an FEM or REM do not differ substantially. If the null hypothesis of the Hausman test is rejected, we use an FEM, rather than an REM. Statistical software such as GRETL helps estimate the robustness of an FEM with respect to heteroscedasticity and/or autocorrelation, and hence robust standard errors. This ensures the efficiency of estimates using an FEM.

\subsection{Sources of Data and Data Collection Procedure}

The major financial data used in this study is gathered from published reports of the State Bank of Pakistan for the period 2000 to 2005. Some variables, such as the amount of noninterest-bearing liabilities, taxes paid, and financial expenses, etc., are extracted from the annual reports of the included firms. The market values of firms' shares during the study period are taken from the Business Recorder. Since, after extracting data on all the required variables, there still remained some missing information, some firms in the industry could not be included in the sample. There are a total of 190 listed textile firms for the said period, with 169 firms categorized as composite, weaving, and spinning, and 21 as other textile firms. This study includes 160 listed firms in its sample, due to the unavailability of data on all textile firms.

\section{Data Analysis}

The methodology outlined in the previous section is applied to our data to estimate the key metrics of cash conversion, receivables, and payables along with inventory conversion. Textile firms are ranked on the basis of WCM performance according to the methodology discussed in Section 3.1. All textile firms are initially ranked on the basis of CCE, DOC, and DWC for a six-year average derived for each firm. All 160 firms are then ranked on the basis of the WCPR model and the top 20 reported.

This analysis also identifies the best-performing company for the said period, according to the respective specialized parameters used as variables for WCM. A similar investigation is conducted to determine 
profitability performance, and the ten best-performing firms are ranked on the basis of ROA, ROE, EVA, and PMS. Finally, the 20 best-performing firms are tabulated on the basis of the profitability model devised earlier.

\subsection{Application of WCPR Model}

\subsubsection{CCE}

When using this variable, some outliers are deleted from the analysis because the gross sales, operating profit, taxes, or depreciation figures for these firms appear to be anomalous-perhaps as a result of gross recording errors-and their use is assumed to yield abnormal CCE values. These deletions are made on the basis of 90 percent homogeneity; only 4.25 percent of the total observations are deleted as outliers.

Figure 1 shows that the textiles sector was at its best in the year 2001 but below average in 2004. The textile firm performing up to par in terms of CCE was Nayab Spinning and Weaving Mills, with a six-year average CCE of 0.96 . The other nine leading firms according to this parameter follow in Table 1.

Figure 1: Average CCE for Textiles Sector (2000-05)

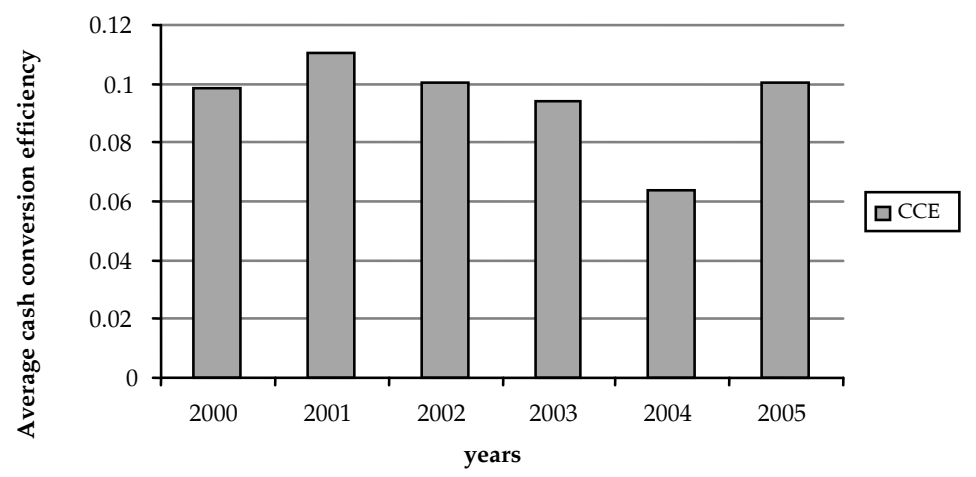


Table 1: Top Ten Textile Firms Ranked by CCE (2000-05)

\begin{tabular}{lcc}
\hline Firm & Six-year average CCE & Rank \\
\hline Nayab Spinning and Weaving Mills Ltd. & 0.96 & 1 \\
Sapphire Textile Mills Ltd. & 0.91 & 2 \\
Chaudry Textile Mills & 0.71 & 3 \\
Mohammad Farooq Textile Mills Ltd. & 0.24 & 4 \\
Dawood Cotton Mills & 0.20 & 5 \\
Legler-Nafees Denim Mills Ltd. & 0.20 & 6 \\
Artistic Denim Mills & 0.20 & 7 \\
Nishat (Chunian) Ltd. & 0.18 & 8 \\
International Knitwear Ltd. & 0.17 & 9 \\
Quality Textile Mills Ltd. & 0.17 & 10 \\
\hline
\end{tabular}

Source: Derived from author's model.

\subsection{2. $D O C$}

Figure 2 shows that the managerial practice of DOC declined industry-wide in the earlier phase. The industry appears to have performed more efficiently during 2002-04, but could not sustain this for long. The best-performing firm over the study period is Sunshine Cotton Mills Ltd., with a six-year average DOC of 15.57. This firm seems to have had a lead with respect to DR and DI. Table 2 shows the leading firms ranked according to the best practice of DOC over the study period.

Figure 2: Average DOC for Textiles Sector (2000-05)

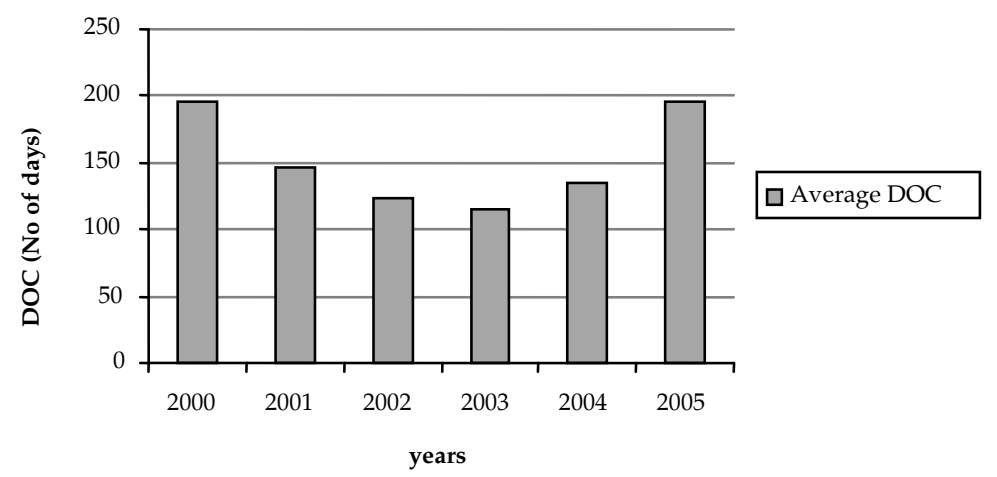


Table 2: Top Ten Textile Firms Ranked by DOC (2000-05)

\begin{tabular}{lcc}
\hline Firm & Six-year average DOC & Rank \\
\hline Sunshine Cotton Mills Ltd. & 15.57 & 1 \\
Noor Silk Mills Ltd. & 21.17 & 2 \\
Chaudry Textile Mills & 22.15 & 3 \\
Service Fabrics Ltd. & 26.73 & 4 \\
Al Qaim Textile Mills & 26.79 & 5 \\
Asim Textile Mills & 27.47 & 6 \\
Polyron Ltd. & 27.54 & 7 \\
Bilal Fibres Ltd. & 36.90 & 8 \\
Khyber Textile Mills Ltd. & 37.41 & 9 \\
Amin Spinning Mills & 38.54 & 10 \\
\hline
\end{tabular}

Source: Derived from author's model.

\subsection{3. $\quad D W C$}

Figure 3 shows that the sampled textile firms performed exceptionally well during 2002-04, where 2003 was the most efficient year on the basis of average DWC. The industry seems to have better managed its DI, DR, and DP in 2003 than in the remaining years, but this might not be a fair conclusion since we know that averages offset movements above and below the central figure.

Figure 3: Average DWC for Textiles Sector (2000-05)

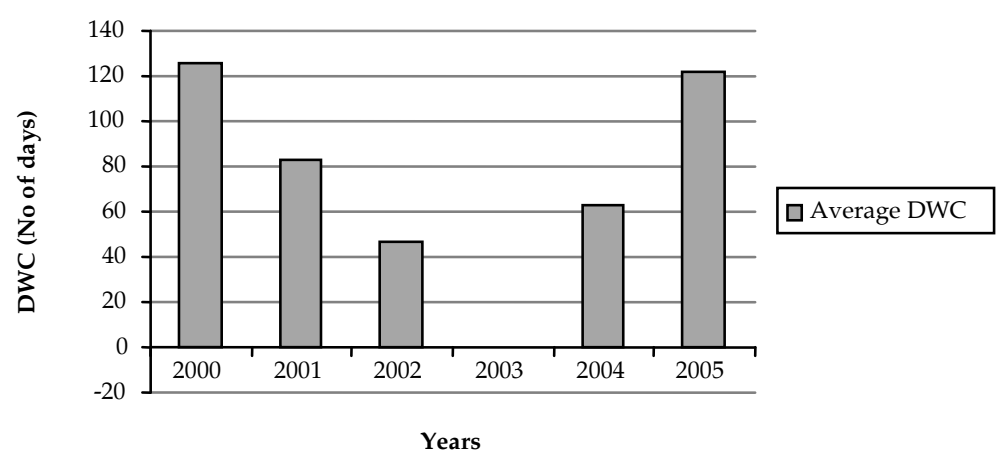

Table 3 lists the sector's leading performers, which appear to have efficiently practiced the management of DWC. Colony Thal Textile Mills is ranked highest, with a six-year average (lowest) value of 0.36 days over the study period. The table accommodates only those firms whose sixyear average DWC falls close to 0 ; firms are ranked on the basis of their distance from 0 on both sides $(+,-)$. 
Table 3: Top Ten Textile Firms Ranked by DWC (2000-05)

\begin{tabular}{lcc}
\hline Firm & Six-year average DWC & Rank \\
\hline Colony Thal Textile Mills & 0.36 & 1 \\
Hamid Textile Mills Ltd. & 0.53 & 2 \\
Mukhtar Textile Mills Ltd. & 3.57 & 3 \\
Khyber Textile Mills Ltd. & -3.78 & 4 \\
Hajra Textile Mills Ltd. & 4.20 & 5 \\
Service Fabrics Ltd. & -4.79 & 6 \\
Ali Asghar Textile Mills & 6.91 & 7 \\
Sally Textile Mills Ltd. & -7.71 & 8 \\
Sunshine Cotton Mills Ltd. & -7.79 & 9 \\
Noor Silk Mills Ltd. & -9.52 & 10 \\
\hline
\end{tabular}

Source: Derived from author's model.

\subsubsection{WCPR}

In order to evaluate the performance of the entire sample, the components of WCM are normalized to bring all ratios to a standard scale that allows comparison. A composite index of WCPR is obtained by taking the weighted average of these components. Firms are ranked using the normalized forms of CCE, DOC, and DWC obtained from the model developed in Section 3.1. We consider the study period 2000-05 in order to rank all 160 firms on the earlier WCM model. The same ranking of all textile firms is later used to compute the rank correlation with their PPRs. Table 4 lists the top 20 firms in terms of WCM efficiency. 
Table 4: Top 20 Textile Firms Ranked by WCPR

\begin{tabular}{|c|c|c|c|}
\hline Firm & Year & $\begin{array}{c}\text { WCPR }=\text { NCCE } * 0.5+ \\
\text { NDOC * } 0.25+\text { NDWC } * 0.25\end{array}$ & Rank \\
\hline Saitex Spinning Mills Ltd. & 2003 & 0.02446 & 1 \\
\hline Pak Fibre Industries Ltd. & 2005 & 0.04004 & 2 \\
\hline Mehr Dastagir Textile Mills Ltd. & 2005 & 0.04712 & 3 \\
\hline Saleem Denim Industries Ltd. & 2002 & 0.06944 & 4 \\
\hline Saleem Denim Industries Ltd. & 2003 & 0.07700 & 5 \\
\hline Saleem Denim Industries Ltd. & 2001 & 0.08236 & 6 \\
\hline Mehr Dastagir Textile Mills Ltd. & 2003 & 0.08862 & 7 \\
\hline Saleem Denim Industries Ltd. & 2000 & 0.08863 & 8 \\
\hline Mehr Dastagir Textile Mills Ltd. & 2002 & 0.08944 & 9 \\
\hline Amin Spinning Mills & 2003 & 0.09296 & 10 \\
\hline Carvan East Fibres & 2003 & 0.09799 & 11 \\
\hline Carvan East Fibres & 2004 & 0.10338 & 12 \\
\hline Mehr Dastagir Textile Mills Ltd. & 2001 & 0.10375 & 13 \\
\hline Elahi Cotton Mills & 2004 & 0.10709 & 14 \\
\hline Carvan East Fibres & 2002 & 0.10998 & 15 \\
\hline Kohinoor Industries Ltd. & 2004 & 0.11450 & 16 \\
\hline Elahi Cotton Mills & 2005 & 0.11483 & 17 \\
\hline Accord Textile Mills & 2003 & 0.11745 & 18 \\
\hline Amin Spinning Mills & 2002 & 0.11913 & 19 \\
\hline Accord Textile Mills & 2002 & 0.11938 & 20 \\
\hline
\end{tabular}

Source: Derived from author's model.

According to the table, seven textile firms dominate the top 20 rankings altogether in different study years. Since we are using a sample of 960 firm-year observations, the model ranks firms on the basis of efficient performance on an ordinal scale and not on the basis of time period, thereby producing a list of firms with the lowest WCPR in any year followed by other firms' higher scores in any other year of the study period.

Table 5 provides a summary of WCM practice by the textiles sector. On average, it shows low-performance benchmarks for the inventory conversion period and receivables collection period, thus producing a longer operating cycle. There are visibly huge gaps between maximum and minimum statistics, implying that there is room for textile firms to improve on these benchmarks. The maximum indicators reflect either sick units or 
the poor quality of figures captured in the data. Even the minimum figures do not seem to be realistic or reliable. CCE takes a negative minimum value in the case of one odd firm that appears to be taking advance receipts before delivering products, which is somewhat believable.

Table 5: Summary of Working Capital Variables for Textiles Sector

\begin{tabular}{lrrrrrr}
\hline Summary & CCE & \multicolumn{1}{c}{ DR } & \multicolumn{1}{c}{ DI } & DOC & \multicolumn{1}{c}{ DP } & $\begin{array}{c}\text { DWC = DOC - } \\
\text { creditors }\end{array}$ \\
\hline Mean & 0.11 & 37.83 & 116.10 & 148.17 & 80.09 & 73.16 \\
Standard & 3.90 & 67.23 & 199.79 & 210.98 & 243.76 & 277.17 \\
dev. & & & & & & \\
Range & 149.58 & $1,624.98$ & $3,414.00$ & $3,534.39$ & $4,961.46$ & $6,611.63$ \\
Minimum & -107.48 & 0.00 & 0.31 & 0.37 & 0.25 & 0.12 \\
Maximum & 42.11 & 1624.98 & $3,414.31$ & $3,534.39$ & $4,961.71$ & $3,488.27$ \\
Count & 954 & 955 & 899 & 947 & 948 & 946 \\
\hline
\end{tabular}

Source: Derived from author's model.

\subsection{Application of PPR Model}

\subsection{1. $R O A$}

Table 6 ranks International Knitwear Ltd. as the top performer on the basis of its six-year average ROA of 20.47, followed by Allawasaya Textile Mills Ltd. with 18.88. Textile firms, like other firms, are morally and legally obligated to generate desirable returns from their employed assets, and market leaders pave the way for other firms to follow. Figure 4 shows that 2000 was the most successful year for the industry, with the highest return generated by assets employed. The subsequent years could not match this extraordinary return. 
Table 6: Top Ten Textile Firms Ranked by ROA (2000-05)

\begin{tabular}{lcc}
\hline Firm & Six-year average ROA & Rank \\
\hline International Knitwear Ltd. & 20.47 & 1 \\
Allawasaya Textile Mills Ltd. & 18.88 & 2 \\
Artistic Denim Mills & 18.13 & 3 \\
Nadeem Textile Mills Ltd. & 17.43 & 4 \\
Nishat (Chunian) Ltd. & 15.13 & 5 \\
Mohammad Farooq Textile Mills Ltd. & 14.27 & 6 \\
Sana Industries Ltd. & 14.13 & 7 \\
Zahur Cotton Mills Ltd. & 14.13 & 7 \\
Gadoon Textile Mills Ltd & 13.70 & 9 \\
Din Textile Mills & 13.37 & 10 \\
\hline
\end{tabular}

Source: Derived from author's model.

Figure 4: Average ROA for Textiles Sector (2000-05)

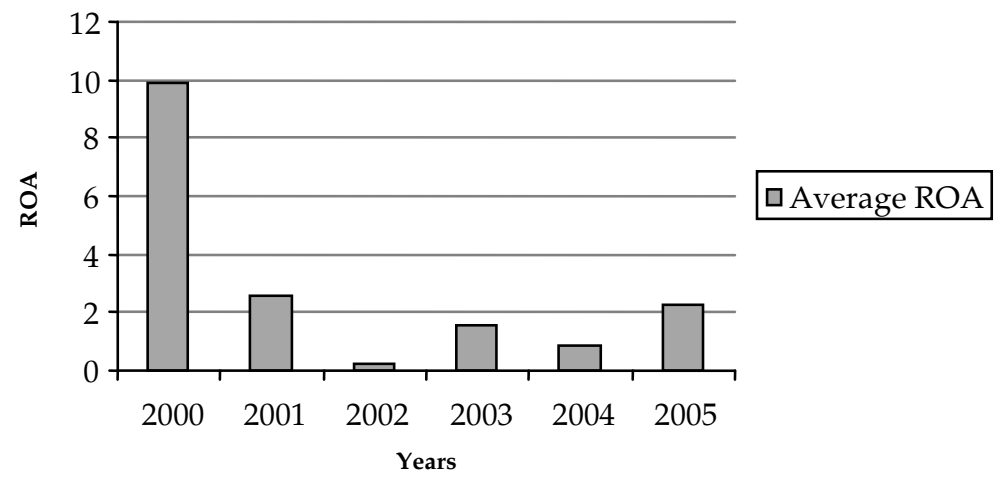

\subsection{2. $R O E$}

Figure 5 shows that 2000 was the sector's best year in term of average ROE achieved, while 2004 shows a negative average ROE. Table 7 lists the best-performing textile firms that were able to create value for equity holders by giving them the highest returns on their invested capital. J. A Textile Mills Ltd. leads with the highest six-year average ROE, 121.90, and is thus ranked first followed by other leading performers in this respect. 
Figure 5: Average ROE for Textiles Sector (2000-05)

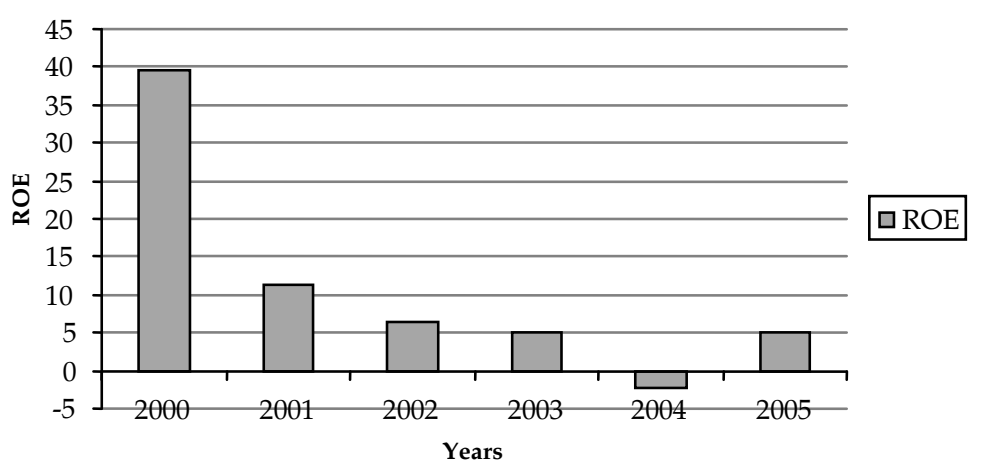

Table 7: Top Ten Textile Firms Ranked by ROE (2000-05)

\begin{tabular}{lcc}
\hline Firm & Six-year average ROE & Rank \\
\hline JA Textile Mills Ltd. & 121.90 & 1 \\
Chakwal Spinning Mills & 98.22 & 2 \\
Hala Enterprises Ltd. & 97.45 & 3 \\
International Knitwear Ltd. & 80.53 & 4 \\
Regent Textile Industries Ltd. & 67.82 & 5 \\
Mohammad Farooq Textile Mills Ltd. & 57.30 & 6 \\
Allawasaya Textile Mills Ltd. & 42.73 & 7 \\
Nishat (Chunian) Ltd. & 40.30 & 8 \\
Nadeem Textile Mills Ltd. & 39.77 & 9 \\
NP Spinning Mills Ltd. & 37.05 & 10 \\
\hline
\end{tabular}

Source: Derived from author's model.

\subsection{3. $E V A$}

The EVA benchmark identifies those firms that have added economic value after compensating for the cost of total funds employed. Deriving the cost of capital is usually a difficult job, and the weight and cost of each factor of capital is utilized in order to calculate the weighted average cost of capital. The data used in this study has several limitations when calculating EVA. A negative EPS results in a negative PE ratio and the cost of equity based on the PE ratio would therefore be negative. Since many firms in the sample exhibited this problem, an estimate of the weighted average cost of capital was calculated for each firm, for a dataset of 414 firm-year observations, and averaged. The cost of capital is estimated as 11.07 percent and used as an industry benchmark to 
calculate the EVA of textile firms. Interestingly, only seven of the entire sample of 160 firms showed a positive EVA on the basis of a six-year average; the remaining 153 had a negative EVA.

Table 8 ranks Artistic Denim Mills first, which has a six-year average EVA of approximately Rs85.9 million. Figure 6 gives an alarming picture of the economic impotency of the textiles sector in showing that average EVA follows a declining trend over the years (in rupees million).

Table 8: Top Ten Textile Firms Ranked by EVA (2000-05)

\begin{tabular}{lcc}
\hline Firm & Six-year average EVA & Rank \\
\hline Artistic Denim Mills & 85.86 & 1 \\
Gadoon Textile Mills Ltd. & 64.11 & 2 \\
Usman Textile Mills Ltd. & 58.11 & 3 \\
Mohammad Farooq Textile Mills Ltd. & 13.63 & 4 \\
International Knitwear Ltd. & 4.51 & 5 \\
Allawasaya Textile Mills Ltd. & 2.77 & 6 \\
Sind Fine Textile Mills Ltd. & 1.68 & 7 \\
Shadab Textile Mills Ltd. & -2.85 & 8 \\
Safa Textiles Ltd. & -3.06 & 9 \\
Sana Industries Ltd. & -5.27 & 10 \\
\hline
\end{tabular}

Source: Derived from author's model.

Figure 6: Average EVA for Textiles Sector (2000-05)

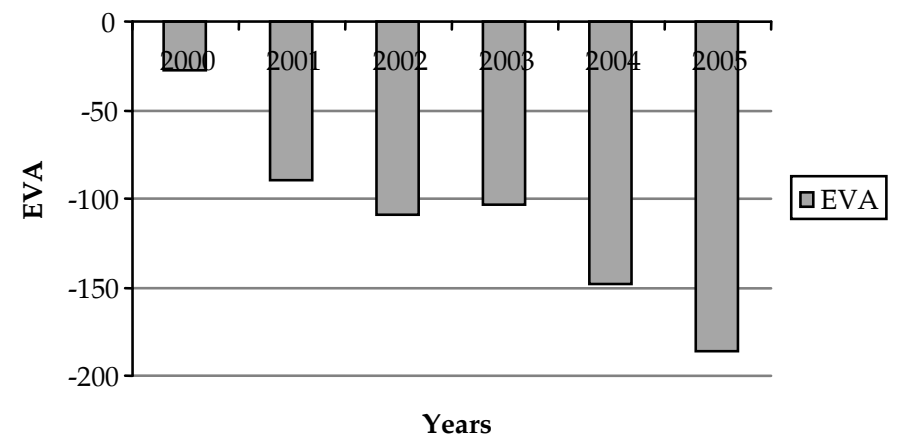

\subsubsection{PMS}

Figure 7 shows that 2004 yielded an average negative net PMS while the remaining years maintained a low positive average net PMS. 
Saitex Spinning Mills and Taj Textile Mills Ltd. share first rank in terms of best performance and the highest six-year average PMS (see also Table 9).

Figure 7: Average Net PMS for Textiles Sector (2000-05)

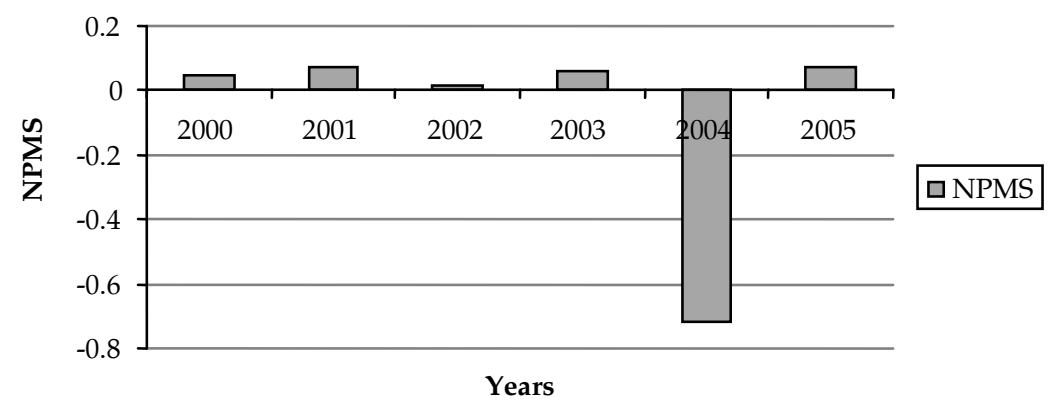

Table 9: Top Ten Textile Firms Ranked by PMS (2000-05)

\begin{tabular}{lcc}
\hline Firm & Six-year average PMS & Rank \\
\hline Saitex Spinning Mills Ltd. & 1.32 & 1 \\
Taj Textile Mills Ltd. & 1.32 & 1 \\
Nayab Spinning and Weaving Mills Ltd. & 1.02 & 3 \\
Sapphire Textile Mills Ltd. & 0.90 & 4 \\
Dawood Cotton Mills & 0.32 & 5 \\
Nadeem Textile Mills Ltd. & 0.21 & 6 \\
Mohammad Farooq Textile Mills Ltd. & 0.21 & 7 \\
Nishat (Chunian) Ltd. & 0.15 & 8 \\
Artistic Denim Mills & 0.15 & 9 \\
Legler-Nafees Denim Mills Ltd. & 0.14 & 10 \\
\hline
\end{tabular}

Source: Derived from author's model.

\subsection{5. $P P R$}

Textile firms are ranked on the basis of profitability and the ratios of ROA, ROE, EVA, and PMS are normalized, as discussed earlier. These calculations consider all 160 firms for the study period 2000-05. Table 10 lists the top 20 firms leading the sector in performance of profitability. According to the four profitability parameters used, Mohammad Farooq Textile Mills Ltd. performed best in 2003 with the lowest weighted average normalized score of 0.19 . 
Table 10 presents a summary of profitability performance metrics for the textiles sector. The average negative EVA reveals that, on average, the sector has not added any economic value to the industry. The cost of utilized funds is more than the accounting profits. Only six firms are seen to have added economic value to the industry while all the others in the sample show a negative EVA (as shown earlier in Table 8).

Table 10: Top 20 Textile Firms Ranked by PPR (2000-05)

\begin{tabular}{lccc}
\hline & \multicolumn{3}{c}{$\begin{array}{c}\text { PPR }=\mathbf{0 . 2 5 N R O A ~ + ~} \\
\text { 0.25NROE + }\end{array}$} \\
Firm & Year & 0.25NEVA + 0.25PMS & Rank \\
\hline Mohammad Farooq Textile Mills Ltd. & 2003 & 0.1912 & 1 \\
International Knitwear Ltd. & 2004 & 0.2386 & 2 \\
Gadoon Textile Mills Ltd. & 2004 & 0.2431 & 3 \\
Amin Spinning Mills & 2004 & 0.2433 & 4 \\
Regent Textile Industries Ltd. & 2000 & 0.2451 & 5 \\
Shahzad Textile Mills Ltd. & 2000 & 0.2471 & 6 \\
Chakwal Spinning Mills & 2003 & 0.2911 & 7 \\
Allawasaya Textile Mills Ltd. & 2000 & 0.2913 & 8 \\
Elahi Cotton Mills & 2005 & 0.2966 & 9 \\
Mehr Dastagir Textile Mills Ltd. & 2005 & 0.2984 & 10 \\
Sapphire Textile Mills Ltd. & 2000 & 0.3002 & 11 \\
JA Textile Mills Ltd. & 2001 & 0.3018 & 12 \\
Nadeem Textile Mills Ltd. & 2004 & 0.3042 & 13 \\
Paramount Spinning Mills Ltd. & 2000 & 0.3059 & 14 \\
Mahmood Textile Mills Ltd. & 2000 & 0.3092 & 15 \\
Din Textile Mills & 2000 & 0.3101 & 16 \\
Fazal Textile Mills Ltd. & 2000 & 0.3103 & 17 \\
Dar-es-salam Textile Mills & 2000 & 0.3148 & 18 \\
Artistic Denim Mills & 2005 & 0.3149 & 19 \\
Ishtiaq Textile Mills Ltd. & 2000 & 0.3155 & 20 \\
\hline
\end{tabular}

Source: Derived from author's model.

The following results reveal the inconsistency of these variables, and indicate a performance discrepancy in the textiles sector. This could denote a bigger problem in Pakistan, as it is possible that financial data (especially earnings) has been misreported, as most of the firms in this sector are family-owned. 


\subsection{Computation of Rank Correlation}

Rank correlation is computed for the ordinal relationship between the performance and working capital of the sampled textile firms. The most popular measure of association is the Spearman's rho (see Lehmann \& D'Abrera, 1998). The Kendall tau_b is another widely used measure of rank correlation, and is computed in this study as an alternative diagnostic. Pearson's rank correlation is computed as an extension of the analysis. All three measures are tested for significance levels.

Table 11 presents our findings, according to which all three diagnostics support an insignificant weak positive rank correlation. This is in agreement with our earlier hypothesis of a positive rank correlation. Many factors can positively affect firm profitability, and therefore a formal regression analysis is used to investigate economic impact. The finding of an insignificant weak positive correlation negates our first hypothesis; this finding is attributed to chance variation.

Table 11: Diagnostics for Rank Correlation

\begin{tabular}{lcc}
\hline \multicolumn{2}{l}{ Kendall's tau_b measure of correlation $\mathbf{( N}=\mathbf{9 6 0})$} & \\
WCPR & PPR \\
WCPR & 1 & $0.002(0.949)$ \\
PPR & $0.002(0.949)$ & 1 \\
\hline Spearman's rho measure of correlation $(\mathbf{N}=\mathbf{9 6 0})$ & \\
WCPR & 1 & $0.002(0.944)$ \\
PPR & $0.002(0.944)$ & 1 \\
\hline Pearson's correlation coefficient $(\mathbf{N}=\mathbf{9 6 0 )}$ & \\
WCPR & 1 & $0.002(0.944)$ \\
PPR & $0.002(0.944)$ & 1 \\
\hline
\end{tabular}

Note: Coefficients are insignificant at the standard levels.

\section{Regression Analysis}

ROA is taken as explained while average DI, average DR, average DP, and cash cycle are taken as explanatory variables. Since there could be a number of reasons affecting profitability, such as pricing policy, sales growth, etc., we use the following control variables: size of the firm, GR, ratio of sales to current assets, and ratio of current assets to total assets. 
The regression is carried out using both the OLS model and FEM as discussed earlier in Section 3.4. Four regression equations are fitted using each of the two models to test the significance of their respective regression coefficients.

\subsection{Results of OLS Model}

Both correlation and regression analysis are carried out between ROA and the explanatory variables using an OLS approach. Table 12 exclusively presents correlations between ROA and the main variables of WCM. Results from this analysis reveal that ROA has a significant negative correlation with DR. This would suggest that better returns may be associated with fast collection of receivables and undue length of DR negatively affect ROA. However such an assumption could be studied by using regression analysis to confirm any economic impact of DR on ROA.

CCE has a significant positive correlation with ROA, surprisingly this should suggest that keeping inventories longer improves profitability. But since this has a link with DP and it is significantly negatively correlated with ROA, this may suggest that textile firms prolong payments to their creditors and accumulate inventories when they are making less profits. A somewhat unexpected finding in Table 12 in this respect is the positive sign of DI which is contrary to theoretical settings. Average DP, expectedly has a negative sign, revealing that delaying payments due improves returns on employed assets.

\section{Table 12: Correlation Coefficients}

\begin{tabular}{lccccc}
\hline & \multicolumn{1}{c}{ ROA } & CCC & DR & DI & DP \\
\hline ROA & \multicolumn{1}{c}{1} & & & & \\
CCC & \multicolumn{1}{c}{$0.098^{* *}(0.003)$} & 1 & & & \\
DR & $-0.167^{* *}(0.000)$ & $0.248^{* *}(0.000)$ & 1 & & \\
DI & $0.044(0.183)$ & $0.773^{* *}(0.000)$ & $0.045(0.177)$ & 1 & \\
DP & $-0.132^{* *}(0.000)$ & $-0.648^{* *}(0.000)$ & $0.026(0.427)$ & $0.022(0.503)$ & 1 \\
\hline
\end{tabular}

Note: ${ }^{* *}$ indicates correlation is significant at 0.01 level (two-tailed).

According to Table 13, there is a significant positive correlation at 1 percent between ROA and firm size. That ROA moves significantly and positively in relation to sales seems to be a straightforward finding. The GR is, however, negatively correlated with ROA, which could be attributed to chance since it is an insignificant negative relationship. 
Additionally, capital asset turnover and the ratio of current assets to total assets are insignificantly correlated with ROA. Other interesting relationships reported in the table are that ROA is significantly and positively correlated with the operating profit margin; and that the ratio of stock to current assets and that of debtors to current assets are significantly and negatively correlated with ROA.

Table 13 exhibits problems of multicollinearity, and many variables indicate spurious relationships. An OLS regression model is fitted on the data next, using the approach discussed in the methodology. The results are summarized in Table 14. Four regression equations are fitted, using one each for the core variable of WCM as an independent variable, i.e., CCC, DI, DR, and DP. While testing the significance of $\beta=0$, we find that the coefficients for firm size, DI, DR, and DP are significantly different from $0(|t|>2)$. However, CCC is insignificant and has a positive sign, which is unexpected.

These findings, however, have little credence since the $\mathrm{R}^{2}$ term reveals the weak explanatory power of the four models, even though they are supported by the results of the F-test at 1 percent, and do a good job of accounting for most variations in the dependent variable (the results of the F-test are significant for all four OLS models). 
Table 13: Correlation Matrix for 160 Textile Firms

\begin{tabular}{|c|c|c|c|c|c|c|c|c|c|c|c|c|c|c|}
\hline & & ROA & OPM & AT & STCA & DTCA & SAPOS & GR & CATA & CLTA & $\mathrm{CCC}$ & DR & DI & DP \\
\hline \multirow[t]{3}{*}{ ROA } & Pearson correlation & 1 & & & & & & & & & & & & \\
\hline & Sig. (two-tailed) & & & & & & & & & & & & & \\
\hline & $\mathrm{N}$ & 960 & & & & & & & & & & & & \\
\hline \multirow[t]{3}{*}{ OPM } & Pearson correlation & $0.268^{* *}$ & 1 & & & & & & & & & & & \\
\hline & Sig. (two-tailed) & 0.000 & & & & & & & & & & & & \\
\hline & $\mathrm{N}$ & 954 & 954 & & & & & & & & & & & \\
\hline \multirow[t]{3}{*}{$\mathrm{AT}$} & Pearson correlation & 0.010 & 0.000 & 1 & & & & & & & & & & \\
\hline & Sig. (two-tailed) & 0.660 & 0.970 & & & & & & & & & & & \\
\hline & $\mathrm{N}$ & 947 & 943 & 947 & & & & & & & & & & \\
\hline \multirow[t]{3}{*}{ STCA } & Pearson correlation & 0.010 & 0.010 & -0.034 & 1 & & & & & & & & & \\
\hline & Sig. (two-tailed) & 0.770 & 0.730 & 0.300 & & & & & & & & & & \\
\hline & $\mathrm{N}$ & 945 & 939 & 932 & 944 & & & & & & & & & \\
\hline \multirow[t]{3}{*}{ DTCA } & Pearson correlation & -0.009 & 0.030 & -0.010 & $0.697^{* *}$ & 1 & & & & & & & & \\
\hline & Sig. (two-tailed) & 0.790 & 0.370 & 0.690 & 0.000 & & & & & & & & & \\
\hline & $\mathrm{N}$ & 944 & 938 & 931 & 944 & 944 & & & & & & & & \\
\hline \multirow[t]{3}{*}{ SAPOS } & Pearson correlation & $0.204^{* *}$ & 0.050 & $0.067^{*}$ & $0.267^{* *}$ & $-0.268^{* *}$ & 1 & & & & & & & \\
\hline & Sig. (two-tailed) & 0.000 & 0.120 & 0.040 & 0.000 & 0.000 & & & & & & & & \\
\hline & $\mathrm{N}$ & 954 & 954 & 943 & 938 & 938 & 954 & & & & & & & \\
\hline \multirow[t]{3}{*}{ GR } & Pearson correlation & -0.020 & 0.010 & -0.020 & -0.010 & 0.010 & 0.040 & 1 & & & & & & \\
\hline & Sig. (two-tailed) & 0.560 & 0.810 & 0.600 & 0.880 & 0.880 & 0.290 & & & & & & & \\
\hline & $\mathrm{N}$ & 860 & 858 & 853 & 847 & 847 & 858 & 860 & & & & & & \\
\hline CATA & Pearson correlation & 0.010 & 0.000 & $0.970^{* *}$ & 0.010 & -0.010 & $0.065^{*}$ & -0.020 & 1 & & & & & \\
\hline
\end{tabular}




\begin{tabular}{|c|c|c|c|c|c|c|c|c|c|c|c|c|c|c|}
\hline & Sig. (two-tailed) & 0.650 & 0.970 & 0.000 & 0.690 & 0.690 & 0.050 & 0.600 & & & & & & \\
\hline & $\mathrm{N}$ & 947 & 943 & 947 & 931 & 931 & 943 & 853 & 947 & & & & & \\
\hline \multirow[t]{3}{*}{ CLTA } & Pearson correlation & 0.010 & 0.000 & $0.972^{* *}$ & 0.010 & -0.010 & 0.060 & -0.020 & $0.998^{* *}$ & 1 & & & & \\
\hline & Sig. (two-tailed) & 0.700 & 0.970 & 0.000 & 0.720 & 0.710 & 0.060 & 0.640 & 0.000 & & & & & \\
\hline & $\mathrm{N}$ & 947 & 943 & 947 & 931 & 931 & 943 & 853 & 947 & 947 & & & & \\
\hline \multirow[t]{3}{*}{$\mathrm{CCC}$} & Pearson correlation & $0.098^{* *}$ & $-0.133^{* *}$ & -0.029 & $0.300^{* *}$ & 0.020 & $0.245^{* *}$ & -0.060 & -0.028 & -0.031 & 1 & & & \\
\hline & Sig. (two-tailed) & 0.000 & 0.000 & 0.380 & 0.000 & 0.600 & 0.000 & 0.080 & 0.400 & 0.340 & & & & \\
\hline & $\mathrm{N}$ & 946 & 945 & 935 & 931 & 931 & 945 & 852 & 935 & 935 & 946 & & & \\
\hline \multirow[t]{3}{*}{ DR } & Pearson correlation & $-0.167^{* *}$ & $-0.634^{* *}$ & -0.020 & 0.000 & $0.098^{* *}$ & $-0.130^{* *}$ & -0.030 & -0.020 & -0.020 & $-0.248^{* *}$ & 1 & & \\
\hline & Sig. (two-tailed) & 0.000 & 0.000 & 0.430 & 0.910 & 0.000 & 0.000 & 0.400 & 0.510 & 0.490 & 0.000 & & & \\
\hline & $\mathrm{N}$ & 959 & 953 & 946 & 944 & 944 & 953 & 859 & 946 & 946 & 946 & 959 & & \\
\hline \multirow[t]{3}{*}{ DI } & Pearson correlation & 0.040 & 0.000 & $-0.238^{* *}$ & $0.421^{* *}$ & -0.013 & $-0.114^{* *}$ & -0.053 & $-0.070^{*}$ & $-0.144^{* *}$ & $0.773^{* *}$ & 0.050 & 1 & \\
\hline & Sig. (two-tailed) & 0.180 & 0.920 & 0.000 & 0.000 & 0.700 & 0.000 & 0.130 & 0.000 & 0.910 & 0.000 & 0.180 & & \\
\hline & $\mathrm{N}$ & 899 & 896 & 891 & 884 & 883 & 896 & 829 & 891 & 935 & 896 & 898 & 899 & \\
\hline \multirow[t]{3}{*}{$\mathrm{DP}$} & Pearson correlation & $-0.132^{* *}$ & -0.027 & -0.028 & 0.030 & -0.003 & $-0.511^{* *}$ & 0.020 & -0.026 & -0.023 & $-0.648^{* *}$ & 0.030 & 0.020 & 1 \\
\hline & Sig. (two-tailed) & 0.000 & 0.400 & 0.400 & 0.400 & 0.940 & 0.000 & 0.600 & 0.430 & 0.480 & 0.000 & 0.430 & 0.500 & \\
\hline & $\mathrm{N}$ & 948 & 946 & 936 & 933 & 932 & 946 & 853 & 936 & 946 & 946 & 947 & 898 & 948 \\
\hline
\end{tabular}

Notes: * and ${ }^{* *}$ indicate correlation is significant at 0.05 level (two-tailed) and 0.01 level (two-tailed), respectively. See Appendix for definition of variables. 
Table 14: Results of OLS Model

Dependent variable $=$ ROA

\begin{tabular}{|c|c|c|c|c|c|c|c|c|c|c|c|c|}
\hline \multirow[b]{2}{*}{ Variable } & \multicolumn{3}{|c|}{ Model 1} & \multicolumn{3}{|c|}{ Model 2} & \multicolumn{3}{|c|}{ Model 3} & \multicolumn{3}{|c|}{ Model 4} \\
\hline & Coefficient & t-value & Sig. & Coefficient & t-value & Sig. & Coefficient & t-value & Sig. & Coefficient & t-value & Sig. \\
\hline Ln_sales & 1.859 & 4.992 & 0.000 & 1.708 & 4.044 & 0.000 & 1.785 & 4.497 & 0.000 & 1.579 & 4.010 & 0.000 \\
\hline GR & -0.001 & -0.794 & 0.427 & -0.001 & -0.858 & 0.391 & -0.001 & -0.816 & 0.415 & -0.001 & -0.793 & 0.428 \\
\hline CA_turn & 0.089 & 0.924 & 0.356 & 0.017 & 0.158 & 0.874 & 0.138 & 1.382 & 0.167 & 0.071 & 0.742 & 0.458 \\
\hline $\mathrm{CA} / \mathrm{TA}$ & 0.001 & 0.018 & 0.986 & 0.002 & 0.061 & 0.952 & 1.653 & 1.426 & 0.154 & -0.009 & -0.018 & 0.986 \\
\hline Inv_days & & & & & & & 0.004 & 1.965 & 0.050 & & & \\
\hline AR_days & & & & -0.037 & -4.932 & 0.000 & & & & & & \\
\hline AP_days & & & & & & & & & & -0.009 & -2.067 & 0.039 \\
\hline CCE & 0.002 & 1.035 & 0.301 & & & & & & & & & \\
\hline $\mathrm{R}^{2}$ & 0.031 & & & 0.056 & & & 0.034 & & & 0.035 & & \\
\hline Durbin-Watson & 1.674 & & & 1.713 & & & 1.679 & & & 1.675 & & \\
\hline $\begin{array}{l}\text { Model significance } \\
\text { (F-test) }\end{array}$ & 5.267 & & 0.000 & 9.820 & & 0.000 & 5.580 & & 0.000 & 5.927 & & 0.000 \\
\hline
\end{tabular}

Note: Ln_sales = natural log of sales as a proxy for firm size, GR = gearing ratio, CA_turn = capital assets turnover or gross working capital ratio. $\mathrm{CA} / \mathrm{TA}=$ current assets $/$ total assets, Inv_days $=$ days in inventory, AR_days $=$ days receivable, $\mathrm{AP} \_$days $=$days payable, $\mathrm{CCE}=\mathrm{cash}$ conversion efficiency. 


\subsection{Results of FEM}

Since our OLS estimates have shown some common statistical problems, their coefficients are not considered fully reliable. Therefore, we apply the Hausman test to decide between using an FEM or REM. The null hypothesis of the test is rejected at 5 percent, which confirms our choice of an FEM. Next, we fit an FEM on the data according to the methodology discussed earlier, and regress ROA on the explanatory variables of WCM, along with four control variables. To capture the firm effect in this balanced panel of 960 firm-year observations, 159 dummies are inserted into the model. Since our data only spans six years, we ignore the time effect on the assumption that six years is too short a time to induce large changes that could have had a significant impact on profitability performance or working capital performance.

Table 15 presents four regression equations: one each for the core variables of WCM, along with the control variables of firm size, leverage ratio, current asset turnover, and ratio of current assets to total assets. The strategy to capture the firm effect works in improving the predictability of the regression models, with a much-improved $\mathrm{R}^{2}$. Modifying the OLS model to an FEM by including dummy variables to capture the firm effect removes the problem of multicollinearity fully, and of autocorrelation partially. Each adapted model now explains variations in ROA better.

Interestingly, while testing for significance, it is found that the coefficients for firm size, DI, and DR, are significantly different from 0 $(|t|>2)$ at 1 percent. DP and CCC are found to be statistically insignificant at all levels. GR has a negative impact on ROA; this coefficient has a negative sign and is significant at 5 percent. Applying the F-test suggests that the four models should be used for estimation purposes. 
Table 15: Results of FEM

Dependent variable $=\mathrm{ROA}$

\begin{tabular}{|c|c|c|c|c|c|c|c|c|c|c|c|c|}
\hline \multirow[b]{2}{*}{ Variable } & \multicolumn{3}{|c|}{ Model 1} & \multicolumn{3}{|c|}{ Model 2} & \multicolumn{3}{|c|}{ Model 3} & \multicolumn{3}{|c|}{ Model 4} \\
\hline & Coefficient & t-value & Sig. & Coefficient & t-value & Sig. & Coefficient & t-value & Sig. & Coefficient & t-value & Sig. \\
\hline Ln_sales & 3.155 & 2.525 & 0.012 & 4.637 & 3.768 & 0.000 & 3.964 & 2.858 & 0.004 & 3.257 & 2.83 & 0.005 \\
\hline GR & -0.008 & -2.180 & 0.030 & -0.007 & -2.133 & 0.033 & -0.007 & -1.800 & 0.072 & -0.007 & -2.171 & 0.03 \\
\hline CA_turn & 0.085 & 0.765 & 0.444 & 0.124 & 1.097 & 0.273 & 0.089 & 0.695 & 0.487 & 0.090 & 0.813 & 0.417 \\
\hline $\mathrm{CA} / \mathrm{TA}$ & -0.023 & -0.354 & 0.724 & -0.300 & -0.126 & 0.900 & -0.034 & -0.449 & 0.654 & -0.024 & -0.364 & 0.716 \\
\hline Inv_days & & & & 0.009 & 2.963 & 0.003 & & & & & & \\
\hline AR_days & & & & & & & -0.049 & -5.843 & 0.000 & & & \\
\hline AP_days & & & & & & & & & & -0.003 & -0.331 & 0.741 \\
\hline CCE & -0.001 & -0.331 & 0.741 & & & & & & & & & \\
\hline $\mathrm{R}^{2}$ & 0.419 & & & 0.425 & & & 0.398 & & & 0.419 & & \\
\hline Durbin-Watson & 2.256 & & & 2.252 & & & 2.280 & & & 2.258 & & \\
\hline $\begin{array}{l}\text { Model significance } \\
\text { (F-test) }\end{array}$ & 3.151 & & 0.000 & 3.185 & & 0.000 & 2.883 & & 0.000 & 3.154 & & 0.000 \\
\hline
\end{tabular}

Note: Ln_sales = natural log of sales as a proxy for firm size, GR = gearing ratio, CA_turn = capital assets turnover or gross working capital ratio. $\mathrm{CA} / \mathrm{TA}=$ current assets $/$ total assets, Inv_days = days in inventory, AR_days = days receivable, AP_days $=$ days payable, CCE = cash conversion efficiency. 


\section{Summary and Conclusion}

The existing literature suggests that there are links between the profitability and efficiency of working capital. This study endeavors to lend credence to this theory on the basis of data on 160 textile firms in Pakistan for the period 2000-05. We investigate empirically the main variables of WCM, i.e., CCE, DWC, and DOC, and identify the best performers on the basis of absolute comparison. Following Anand and Gupta (2001), we formulate a weighted average index by normalizing the absolute variables and ranking all the textile firms in terms of overall working capital performance in order to identify the 20 best performers.

The study also examines the relationship between WCM and profitability. For this purpose, it develops a profitability benchmark based on four variables: ROA, ROE, EVA, and PMS. All the textile firms sampled are ranked according to each of these measures in order to identify the top ten performers in the industry. The profitability indices are normalized and we establish a PPR model by using a weighted average approach. The 20 best performers on the basis of this model are identified in terms of overall profitability performance. The ranked firms are tested for rank correlation using the Spearman's rho, Kendall tau_b, and Pearson's correlation coefficients.

We find that the textile firms show insignificant and weak positive rank correlation between the two ordinal scales devised for WCM and profitability. According to Pearson's correlation coefficient, there is insignificant positive correlation between ROA and DI. Both DR and DP are significantly and negatively correlated with ROA, while CCC is significantly and positively correlated with ROA.

In the regression analysis that follows, ROA is taken as dependent on the main WCM variables: CCC, DI, DR, and DP. We use OLS and fixed effect models to find causation for ROA by estimating regression coefficients. The models use firm size, GR, current assets turnover, and the ratio of current assets to total assets as control variables. The OLS model reveals that textile firms could improve their returns by adopting sound strategies for collection, since DP has an established significant economic impact on the assets employed by firms. This model also lends credence to the assumption that the less profitable firms rely on credit from their suppliers and prolong their due payments. 
We capture the firm effect using dummy variables. The findings of the fixed effect model reveal that firm size is significant along with the variables DI and DR in all the four models fitted at a 1 percent level. Both DP and CCC, however, are insignificant at all levels. The sign of the DI coefficient remains a matter of concern, while CCC has the expected negative sign that suggests that firms could add value by improving their cash cycles.

To conclude, we infer that the textiles industry has established a weak positive rank correlation between working capital performance and profitability performance. The finding is still limited by the insignificance of the relationship, and could be attributed to chance. Another limitation is the study's design, which relies on the weighted average concept of developing working capital and profitability models, using subjective weights. A different weighting criterion might have produced contrary results.

The study establishes that the inventory conversion period, receivables' collection period, payables' deferral period, and CCC all have an economic impact on the ROA of textile firms in Pakistan. Statistical reasoning shows that the components of WCM affect these firms' returns. The issue has scope for further research to improve the weighting criterion used to rank firms by WCM and profitability, and to search for causal relationships by identifying other management practices in the industry that could improve profitability. 


\section{References}

Anand, M., \& Gupta, C. P. (2001). Working capital performance of corporate India: An empirical survey for the year 2000-2001. Management and Accounting Research, 4(4), 35-65.

Anand, M., \& Malhotra, K. (2007). Working capital performance of corporate India: An empirical study. ICFAI Journal of Applied Finance, 13(1), 46-81.

Burki, S. J. (2008). Industrial policy: Domestic challenges, global imperatives, and Pakistan's choices [Special Edition]. Lahore Journal of Economics, 13, 23-34.

Deloof, M. (2003). Does working capital management affect profitability of Belgian firms? Journal of Business, Finance and Accounting, 30(34), 573-588.

Garcia-Teruel, P. J., \& Martinez-Solano, P. (2007). Effects of working capital management on SME profitability. International Journal of Managerial Finance, 3(2), 164-177.

Gujrati, D. N. (2003). Basic econometrics (4th ed.). New York, NY: McGrawHill.

Hausman, J. A. (1978). Specification tests in econometrics. Econometrica, $46,1251-1271$.

Kemal, A. R. (2005). Key issues in industrial growth in Pakistan [Special Edition]. Lahore Journal of Economics, 10, 49-74.

Khan, S., Shah, A. M., \& Hijazi, S. T. (2006). Impact of working capital management on the profitability of firms: Case of listed Pakistani companies. Journal of Social Sciences, 13, 41-50.

Lazaridis, I., \& Tryfonidis, D. (2006). Relationship between working capital management and profitability of listed companies in the Athens stock exchange. Journal of Financial Management and Analysis, 19(1), 26-35.

Lehmann, E., \& D'Abrera, H. (1998). Nomparametrics: Statistical methods based on ranks (Revised ed.). Englewood Cliffs, NJ: Prentice-Hall. 
Lyroudi, K., \& Lazaridis, J. (2000). The cash conversion cycle and liquidity analysis of the food industry in Greece. Retrieved from Social Science Research

Network, http:/ / papers.ssrn.com/paper.taf?abstract_id=236175

Padachi, K. (2006). Trends in working capital management and its impact on firms' performance: An analysis of Mauritian small manufacturing firms. International Review of Business Research Papers, 2(2), 45-58.

Raheman, A., \& Nasr, M. (2007). Working capital management and profitability: Case of Pakistani firms. International Review of Business Research Papers, 3(1), 279-300.

Shah, S. M., \& Sana, A. (2006). Impact of working capital management on the profitability of oil and gas sector of Pakistan. European Journal of Scientific Research, 15(3), 301-307.

Shin, H. H., \& Soenen, L. (1998). Efficiency of working capital and corporate profitability. Financial Practice and Education, 8(2), 37-45.

Stewart, G. B. (1991). The quest for value: A guide for senior managers. New York, NY: HarperCollins.

Yazdani, T. (1999). Pakistan's textiles and anti-dumping laws. Lahore Journal of Economics, 4(2), 127-150. 


\section{Appendix}

\section{List of Abbreviations}

\begin{tabular}{|c|c|c|c|}
\hline $\mathrm{N}_{\mathrm{cce}}$ & $\begin{array}{l}\text { Normalized cash conversion } \\
\text { efficiency }\end{array}$ & $\mathrm{N}_{\text {roa }}$ & Normalized return on assets \\
\hline $\mathrm{h}_{\mathrm{comr}}$ & $\begin{array}{l}\text { Highest overall cash operating } \\
\text { margin ratio }\end{array}$ & $h_{\text {roa }}$ & Highest overall return on assets \\
\hline $\mathrm{c}_{\mathrm{comr}}$ & $\begin{array}{l}\text { Company cash operating margin } \\
\text { ratio }\end{array}$ & $\mathrm{C}_{\text {roa }}$ & Company return on assets \\
\hline $1_{\text {comr }}$ & $\begin{array}{l}\text { Lowest overall cash operating } \\
\text { margin ratio }\end{array}$ & $1_{\text {roa }}$ & Lowest overall return on assets \\
\hline $\mathrm{N}_{\mathrm{doc}}$ & Normalized days operating cycle & $\mathrm{N}_{\text {roe }}$ & Normalized return on equity \\
\hline $1_{\text {doc }}$ & $\begin{array}{l}\text { Lowest overall days operating } \\
\text { cycle }\end{array}$ & $\mathrm{h}_{\text {roe }}$ & $\begin{array}{l}\text { Highest normalized return on } \\
\text { equity }\end{array}$ \\
\hline $\mathrm{c}_{\mathrm{doc}}$ & Company days operating cycle & $\mathrm{C}_{\text {roe }}$ & $\begin{array}{l}\text { Company normalized return on } \\
\text { equity }\end{array}$ \\
\hline $\mathrm{h}_{\mathrm{doc}}$ & $\begin{array}{l}\text { Highest overall days operating } \\
\text { cycle }\end{array}$ & $1_{\text {roe }}$ & $\begin{array}{l}\text { Lowest normalized return on } \\
\text { equity }\end{array}$ \\
\hline $\mathrm{N}_{\mathrm{dwc}}$ & Normalized days working capital & $\mathrm{N}_{\text {npms }}$ & $\begin{array}{l}\text { Normalized net profit margin on } \\
\text { sales }\end{array}$ \\
\hline $1_{\mathrm{dwc}}$ & $\begin{array}{l}\text { Lowest overall absolute days } \\
\text { working capital }\end{array}$ & $\mathrm{h}_{\text {npms }}$ & $\begin{array}{l}\text { Highest normalized net profit } \\
\text { margin on sales }\end{array}$ \\
\hline$c_{d w c}$ & $\begin{array}{l}\text { Company absolute days working } \\
\text { capital }\end{array}$ & $\mathrm{C}_{\text {npms }}$ & $\begin{array}{l}\text { Company normalized net profit } \\
\text { margin on sales }\end{array}$ \\
\hline $\mathrm{h}_{\mathrm{dwc}}$ & $\begin{array}{l}\text { Highest overall absolute days } \\
\text { working capital }\end{array}$ & $1_{\text {npms }}$ & $\begin{array}{l}\text { Lowest normalized net profit } \\
\text { margin on sales }\end{array}$ \\
\hline NCFFOA & $\begin{array}{l}\text { Net cash flow from operating } \\
\text { activities }\end{array}$ & $\mathrm{N}_{\text {eva }}$ & $\begin{array}{l}\text { Normalized economic value } \\
\text { added }\end{array}$ \\
\hline EBIT & Earnings before interest and taxes & $\mathrm{h}_{\text {eva }}$ & $\begin{array}{l}\text { Highest normalized economic } \\
\text { value added }\end{array}$ \\
\hline $\mathrm{D}$ & Depreciation & $\mathrm{C}_{\text {eva }}$ & $\begin{array}{l}\text { Company normalized economic } \\
\text { value added }\end{array}$ \\
\hline $\mathrm{T}$ & Tax & $1_{\text {eva }}$ & $\begin{array}{l}\text { Lowest normalized economic } \\
\text { value added }\end{array}$ \\
\hline SR & Sales revenue & NOPAT & $\begin{array}{l}\text { Net operating profit after } \\
\text { interest and taxes }\end{array}$ \\
\hline LnS & Natural log of sales & DI & Days in inventory \\
\hline GR & Gearing ratio & DR & Days receivable \\
\hline GWCTR & $\begin{array}{l}\text { Gross working capital turnover } \\
\text { ratio }\end{array}$ & DP & Days payable \\
\hline $\mathrm{Ct} 1$ & $\begin{array}{l}\text { Current assets divided by total } \\
\text { assets }\end{array}$ & $\mathrm{CCC}$ & $\begin{array}{l}\text { Cash conversion cycle }=\text { days in } \\
\text { inventory }+ \text { days receivable }- \\
\text { days payable }\end{array}$ \\
\hline $\mathrm{Ct} 2$ & $\begin{array}{l}\text { Current liabilities divided by total } \\
\text { assets }\end{array}$ & ExWC & $\begin{array}{l}\text { Denotes days in inventory, days } \\
\text { payable, days receivable, and } \\
\text { cash conversion cycle } \\
\text { subsequently }\end{array}$ \\
\hline
\end{tabular}

